DOI: 10.1515/auseur-2015-0015

\title{
Illegal Immigration and Fight against Illegal Migration in Member States of the European Union
}

\author{
Kamilla SHERYAZDANOVA \\ Academy of Public Administration, Astana, Kazakhstan
}

\begin{abstract}
In the modern world, processes of migration are expected to contribute to economic development, the interchange of progressive technologies and knowledge as well as the blending of cultures. Solving the problems linked to migration processes is an important task to be accomplished by various state policies of European Union member countries. Both internal and external reasons explain why such policies are treated with much consideration nowadays. The present paper describes the development of European Union regulations on immigration and asylum, while tackling certain primarily legal - aspects of immigration policies, too. Its conclusion based on the discussion of processes and legal provisions relates to the possible future of Europe.
\end{abstract}

Keywords: processes of migration, European Union, illegal migration, regulation of migration

\section{Introduction}

The concept 'illegal migration' applies to a number of distinct phenomena. The term designates primarily - actions of (groups of) - citizens stemming from third countries, who illegally enter the territory of a Member State of the European Union (hereinafter, also EU) by land, water, or air (the latter case includes the transit zones of airports, too.) In most situations, the act itself is carried out either using counterfeit travel documents, or facilitated by organized criminal networks involved in smuggling various merchandise or in human trafficking. Furthermore, a large number of people possessing valid visas or enjoying the visa-free regime applicable to their countries travel legally to EU Member States for short visits. However, some of them choose to stay in the respective countries for longer periods than the ones specified in their visas or allowed by the visa-free regime, while others change the purpose of their stay without official permission. Finally, the term is also used for 
those asylum-seekers, who refuse to leave their target countries although a final negative decision has been taken in what concerns their applications.

Illegal migration streams can be estimated using various quantitative indicators; e.g., the number of entry denials, the number of illegal immigrants detained on the borders or within the territory of EU countries, the number of petitions for naturalization and asylum as well as the number of rejected applications and expulsions. Taking into account the significant number of persons, who legally enter EU countries and then 'overstay' their legal periods is also useful. Several assessments of annual illegal immigration streams targeting the EU that were carried out on the basis of these indicators yielded six-digit numbers. ${ }^{1}$

\section{Legal Milestones in Regulating Contemporary Migration Processes in Europe}

In recent years, illegal immigration became part of EU member states' internal lives, although various laws forbidding illegal stay and employment of aliens have been adopted. Moreover, it became obvious that illegal migrants represent a threat to the national security of both the accepting and the transit countries, since the states cannot keep records of these people, while they are excluded from the system of official employment, taxation, and social protection. Other negative phenomena are also linked to illegal migration. Namely: it provides labour force for the shadow economy; it represents a potential source of criminal activities; it involves epidemiological risks; and, finally, it tends to aggravate ethnicallybased conflicts in society, while being considered a nutrient of xenophobia and radical nationalism. Transnational criminal communities help roughly 1 million illegal immigrants yearly to leave their countries. According to available data, the annual global income generated by the smuggling of people (and/or human trafficking) exceeds 7 billion US dollars. The fact that illegal immigrants willingly accept all terms offered to them in exchange for the possibility to travel to Europe and get a job explains this state of affairs. However, why do employers take the risk of hiring illegal workers possessing no documents? They do so not because the migrant is a better employee than somebody else, but because (s)he accepts a lower wage, is always obedient, will never refuse to work and if the employer becomes dissatisfied with her/him, (s)he will be able to dismiss the illegal worker without any consequences. ${ }^{2}$

1 Юдина Т.Н. О социологическом анализе миграционных процессов // Социологические исследования. - 2002. - №10. - C. 22.

2 Communication from the Commission to the Council and the European Parliament on a common policy on illegal immigration. (COM/2001/0672 final) [http://eur-lex.europa.eu/legal- 
The Plan of Tampere was adopted in 1999. According to the Plan, the European Union started to develop a uniform system of providing political asylum and allowing legal entry to certain immigrants while strengthening her external borders to block the access of illegal immigrants. In July 2001, the Commission initiated a new method of open co-ordination between Member States in the area of immigration and asylum policy. The Commission's intention was to encourage information exchange about practical results and plans. Furthermore, the main purpose of this new method was to gradually harmonize legislation and policies of Member States, which was deemed necessary, above all else, as a first step towards laying the foundations of a general system for providing political asylum. ${ }^{3}$ The latter system had a threefold purpose: (1) defining uniform standards for considering applications for asylum; (2) mandatory record keeping of people, who expect an answer to their applications, and of their situations, too; (3) harmonization of national legislations in terms of defining refugee status.

The Hague Programme was adopted in 2004 and defined the following objectives regarding immigration policy:

- to develop an all-European system of political asylum, including the general procedure of providing it;

- to create employment possibilities for aliens within the European Union, taking into account various requirements of labour markets;

- to establish all-European standards for integration of migrants in host countries;

- to strengthen partnerships with third countries in order to regulate illegal immigration;

- to develop policies for returning illegal immigrants to their home countries;

- to use biometric and information systems more effectively.

In December 2005, the Council adopted - as part of the Hague Programme - a directive on the status of refugees. ${ }^{4}$ This was an important step in further developing the Dublin Convention, ${ }^{5}$ towards creating the all-European regulation on political asylum. The said Directive includes regulations regarding the harmonization of granting and withdrawing refugee status in EU member countries. These regulations are laid down as minimum standards applicable to the respective procedures. In February 2006, the Commission also established

content/EN/TXT/?uri=CELEX: 52001DC0672], accessed on the $25^{\text {th }}$ of December 2015.

The Hague Programme. 10 priorities for the next five years. [http://eur-lex.europa.eu/legalcontent/EN/TXT/?uri= uriserv:116002], accessed on the $25^{\text {th }}$ of December 2015.

4 Council Directive 2005/85/EC of 1 December 2005 on minimum standards on procedures in Member States for granting and withdrawing refugee status. [http://eur-lex.europa.eu/legalcontent/GA/TXT/?uri=URISERV:133140], accessed on the $27^{\text {th }}$ of December 2015.

5 Convention determining the State responsible for examining applications for asylum lodged in one of the Member States of the European Communities - Dublin Convention. (97/C 254/01) [http://eur-lex.europa.eu/legal-content/ EN/ALL/?uri=CELEX\%3A41997A0819\%2801\%29], accessed on the $27^{\text {th }}$ of December 2015. 
measures for strengthening co-operation in terms of receiving political asylumseekers. Thus, the Commission offered a working programme of expeditious interaction between countries in order to achieve better co-operation efficiency.

The EU's plan of global actions against illegal immigration and human trafficking ${ }^{6}$ was adopted by the Council in February 2002. The main points of the plan tackle the improvement of visa policies, the exchange and analysis of data on immigration as well as various measures regulating the regime of border crossing and repatriation. All these issues have been considered when developing the European Union's strategy of fighting illegal immigration.

At the beginning of 2002 and on the basis of the said Plan, the Commission published a document ${ }^{7}$ dealing with the prospective return policy on illegal migrants. Its intent was to open and generate debate on measures for returning illegal immigrants to their home countries as a component of European immigration policy and, further, on the integration of immigration policy into a comprehensive foreign policy of the European Union. Furthermore, the High Level Working Group on Asylum and Migration - consisting of high officials and set up during the summit in Tampere - submitted a report on actions regarding third countries that are not interested to co-operate with the EU in combating illegal immigration.

It is rather obvious and various legal instruments adopted by the EU also state that the protection of the Union's external borders is the most important mechanism for counteracting illegal immigration. Council Regulation (EC) No 539/2001 of 15 March 2001 listing the third countries whose nationals must be in possession of visas when crossing the external borders and those whose nationals are exempt from that requirement stipulates the conditions governing foreigners' entry to EU territory. Among other things, this regulation establishes white and black lists for citizens of third countries.

The intensive process of developing uniform rules for border protection started on the eve of the EU's expansion to the East. In 2001, the Commission proposed the creation of a European Border Guard. Banking on preparatory work carried out by the Commission and the relevant committees of the Council, the Plan for the Joint EU Border Protection was elaborated by June 2002.

The decision that external borders shall be protected by joint efforts of all EU Member States was unanimously made. Implementation of the aforementioned plan progressed gradually. In the beginning, the reference textbook including the detailed description of rules and procedures ensuring uniform external border protection was published. Presently, joint border guard training sessions on

6 Proposal for a comprehensive plan to combat illegal immigration and trafficking of human beings in the European Union. Official Journal, C 142, 14 June 2002. [http://eur-lex.europa.eu/ legal-content/EN/TXT/?uri=URISERV: 133191b], accessed on the $25^{\text {th }}$ of December 2015.

7 Green paper on a community return policy on illegal residents. (COM/2002/175 final) [http:// eur-lex.europa.eu/ legal-content/EN/TXT/?uri=celex:52002DC0175], accessed on the $25^{\text {th }}$ of December 2015. 
general rules and on using methods of uniform practice are being planned. The European Academy of Border Guards was set up in order to accomplish these tasks. The exchange of experts, consultants, and communication officers who will be involved in training the future students of the Academy is a necessary preparatory stage. Finally, the last step in this process of preparation will be the creation of international teams to patrol the external borders of the EU, but only in addition to national border guards, without replacing the latter. ${ }^{8}$

The European Agency for the Management of Operational Cooperation at the External Borders (hereinafter, Frontex - from the French expression Frontières extérieures meaning external borders), having its seat in Warsaw, started functioning in June 2005. The Agency's tasks are the following: (a) to co-ordinate co-operation between Member States in terms of border protection, (b) to help establishing border divisions, and (c) to establish uniform standards of border protection. For the future, the European Commission plans various adjustments to the functioning of the European surveillance system (hereinafter, Eurosur), which uses drones, reconnaissance aircraft, offshore and satellite remote sensors in order to track illegal immigration into European Union countries. ${ }^{9}$ Thus, cooperation within the Frontex agency will be enhanced and it will be possible to implement interaction between the relevant national structures of all EU Member States. To support the attainment of this objective, the Commission increased the annual budget of the agency to 60 million euros in 2008. Moreover, in emergency situations, the resources of the External Borders Fund ${ }^{10}$ may also be used.

At the EU Summit in December 2005, the Council defined the Global Approach to Migration as 'the complex of priority actions for reduction of inflow of illegal immigrants, which is followed by loss of human life and also for ensuring the return of migrants home'. ${ }^{11}$ This approach was offered by the Council as an effective solution to the migration issue since it is related to different areas of policy within the European Union; that is, not only to the Union's self-identification as a 'space of freedom, safety and justice' but also to the elaboration of policies, to international relations, employment and neighbourhood issues.

The strategy adopted by the EU gave the next political impulse to developing such a supranational approach, which includes the regulation of (illegal and legal labour) migration of citizens stemming from third countries as well as external

8 Кудрина Л. В. Пространство свободы, безопасности и правопорядка. // Европейский Союз: факты и комментарии. - №48. [http://www.edcaes.ru/site/ru/union/archive/vipusk_48.html], accessed on the $1^{\text {st }}$ of October 2015.

9 Wikipedia. The Free Encyclopedia. sv Eurosur. [https://en.wikipedia.org/wiki/Eurosur], accessed on the $25^{\text {th }}$ of December 2015.

10 European Commission: Migration and Home Affairs. External Borders Fund. [http://ec.europa. eu/dgs/home-affairs/financing/fundings/migration-asylum-borders/external-borders-fund/ index_en.htm], accessed on the $25^{\text {th }}$ of December 2015.

11 Потёмкина О. Иммиграционная политика ЕС: от Амстердама до Лиссабона // МЭ и МО. - 2010. - № 4. - C. 48 . 
measurement of immigration policy indicators. The vote on the project of creating the European Return Fund ${ }^{12}$ - aimed at improving the return management regarding migrants - took place in November 2007 in the Civil Liberties Committee of the European Parliament. Furthermore, Members of the European Parliament supported the idea of voluntary return and proposed closer co-operation with local authorities as well as financial aid to citizens of third countries, who made the decision to return home voluntarily. An important step regarding both the protection of rights enjoyed on the territory of the European Union by illegal immigrants and the fight against illegal immigration was the framework decision on introducing uniform criminal sanctions applicable to employers using the work of illegal immigrants, adopted on the $16^{\text {th }}$ of May 2007. ${ }^{13}$

The shadow economy using the work of illegal immigrants in agriculture, construction, and the sector of services contributes in this manner with a proportion of $7-16 \%$ to the GDP of the member states. Nevertheless, most illegal employees work in conditions reminding of forced labour. Only $3 \%$ of European companies are subjected to annual checks regarding the use of illegal labour, whereas for ensuring a minimum level of state oversight it is necessary to carry out inspections at not less than $10 \%$ of all companies and certain employers. These figures prove that the relevant governmental institutions practically do not supervise this activity.

The European Pact on Immigration and Asylum was unanimously approved by the leaders of the 27 Member States on the $16^{\text {th }}$ of October 2008 during the Summit of the European Council in Brussels. The document is a political agreement made by EU member states on supporting the involvement of highly qualified specialists from third countries in the fight against illegal immigration, in the strengthening of border control measures, and in the co-ordination of policies regarding political asylum. The Pact states that legal migration shall reflect the wills of both the migrant and the country to which (s)he travels (for mutual benefit). Hence, this legal instrument stipulates that each and every Member State is free to independently lay down the conditions of inviting legal migrants and to limit their numbers. However, it also specifies that legal migration quotas shall be established in partnership with the migrants' countries of origin. Finally, in my opinion, the two most important principles laid down in the Pact are: (i) the co-operation between the Member States, the Commission, and the countries of origin from where migrants come and (ii) the requirement that all Member States shall 'readmit their own nationals who are staying illegally on the territory of another State'. ${ }^{14}$

12 [European Commission: Migration and Home Affairs.] Return Fund. [http://ec.europa.eu/ dgs/home-affairs/ financing/fundings/migration-asylum-borders/return-fund/index_en.htm], accessed on the $25^{\text {th }}$ of December 2015.

13 Потёмкина О. Сотрудничества в сфере внутренних дел и правосудия // Европейский союз на пороге XXI века: выбор стратегии развития / Под ред. Борко Ю. А. и Буториной О. В. - М.: Эдиториал УРСС, 2001. - C. 45.

14 [Council of the European Union:] European Pact on Immigration and Asylum. [http://register. 
Furthermore, in order to limit the illegal inflow of labour force to EU territory, a document binding almost all Member States, namely the Directive 2009/52/ EC of the European Parliament and of the Council of 18 June 2009 providing for minimum standards on sanctions and measures against employers of illegally staying third-country nationals, was adopted on the $18^{\text {th }}$ of June 2009. In fact, the directive practically bans any kind of employment of illegal immigrants and stipulates a number of sanctions as well as a wide range of preventive, recovery, and retaliatory measures. For instance:

- employers are bound to make sure that citizens of third countries, who work for them, are legally staying on the territory of the respective Member State and to inform the competent authorities on employing legal migrants;

- employers shall pay penalties depending on the number of employed illegal immigrants and cover the expenses of their return trip, too;

- employers of illegal immigrants shall be deprived of certain rights and privileges such as the right to receive aids and grants from public authorities, the right to participate in public procurement procedures and be awarded state contracts, etc.;

- Member States shall carry out 'effective and appropriate inspections' on their territories in order 'to ensure a satisfactory level of enforcement of the Directive'. ${ }^{15}$

However, the Directive does not regulate the responsibility of illegal workers. Instead, this matter shall be regulated independently by the Member States. Nonetheless, the document contains a set of rules which protect the interests of immigrants. For example, employers are obliged to pay them full salaries and to make other payments connected to their employment (i.e., taxes and benefits) as if they worked on legal grounds. Last but not least, after the deadline set for transposing the Directive into national legislation (the $20^{\text {th }}$ of July 2011), its provisions shall apply on the entire territory of the European Union, except for three member states (Denmark, Ireland, and the United Kingdom), which opted out in accordance with the Treaties of the European Union. ${ }^{16}$

Still, one must preliminarily conclude that until now the European Union has failed to set up a network of institutions dealing with the various aspects of migration. For now, all specific issues connected to migration are dealt with on national level, while only the framework regulations on migratory processes

consilium.europa. eu/doc/srv?l=EN\&f=ST\% $2013440 \% 202008 \% 20 I N I T]$, accessed on the $25^{\text {th }}$ of December 2015. p. 7.

15 Потёмкина О. Сотрудничества в сфере внутренних дел и правосудия // Европейский союз на пороге XXI века: выбор стратегии развития / Под ред. Борко Ю.А и Буториной О. В. - М.: Эдиториал УРСС, 2001. - C. 49.

16 Потёмкина О. Сотрудничества в сфере внутренних дел и правосудия // Европейский союз на пороге XXI века: выбор стратегии развития / Под ред. Борко Ю.А и Буториной О. В. - М.: Эдиториал УРСС, 2001. - C. 51. 
have been adopted at EU level. The regulation of migratory processes is being interpreted as a specific and peculiar area of social policies carried out by states through intricate systems of administrative, legal, organizational, economic, and informational methods. It is important to note that national regulations, fortunately, take into account apparent tendencies of interstate and external migration.

Regulation of external labour migration is the most important element of migration policy. The main stipulations in this respect refer to:

- the legal, political, and professional status of migrant workers;

- various institutional services dealing with migrant workers;

- interstate agreements on migrant workers.

Each country independently establishes and defines the number of allowed immigrants, their professional qualifications, the age and gender structure of migrant workers as well as their period of stay. At present, EU Member States face a number of challenges and the future of the European Union might depend on the manner how the actors in the process will cope with these challenges. The main challenges (or problems) are listed below:

1) Regulation of immigration streams that evolved from the status of an incidental phenomenon to being a constant concern;

2) Development and implementation of measures for adaptation of immigrants to working conditions, life, and culture in the country of residence;

3) Correction of the relationship established with illegal immigrants and the redefinition of the refugee status as required by contemporary conditions;

4) Searching for long-term solutions to mitigate the pressure exerted by various demographic factors upon economic development by means of internationally adopted measures in the field of investments, trade, co-operation, and observance of fundamental human rights.

Fight against these problems occurs on two levels: the national and the regional level. The increased scale and intricate structure of migration imposed the reinterpretation of concepts like refugees and illegal immigrants. According to the Dublin Convention, refusal by any EU Member State to grant political asylum to a migrant does not allow the 'refused person' to submit a similar application to the authorities of another EU country. ${ }^{17}$

I. Tsapenko notes that drastic (punitive) measures are applied against carriers of illegal migrants. According to the Convention on International Civil Aviation (1948) and the Schengen Agreement (1990), air carriers in EU countries are responsible for appropriately checking the entry documents of passengers, while government bodies shall exercise control of foreigners and assist air carrier companies. Furthermore, air carriers shall return 'illegal' aliens to their points of departure or another place where they can be accepted.

17 Гудвин-Гилл Г.С. Статус беженца в международном праве. М., 1997. 
Arrest and deportation of illegal immigrants are extreme measures. In this line of reasoning, critics consider the deportation procedure inhumane and stress that it involves considerable expenses, too. Still, let us briefly examine various penalties stipulated in French legislation. In accordance with it, an alien who illegally arrives to the country and does not possess identification documents shall be imprisoned for a period of seven to ten days. If, after this period, (s)he still refuses to identify her/himself by name, (s)he can be deprived of her/his freedom for two or three months on the basis of a ruling made by the Correctional Court. Finally, extremely severe measures are adopted against foreign criminals. ${ }^{18}$

Host countries insist that responsibility for illegal immigrants should be borne by the countries crossed by them before arrival. Bilateral agreements recognizing such a responsibility were concluded during the 1990s between Spain and Morocco, the Netherlands and Morocco, Germany and Vietnam as well as Germany and the Czech Republic.

Article 19 of the Charter of Fundamental Rights of the European Union forbids collective expulsions (of certain categories of persons - for example, citizens of a certain state - without consideration of each individual case)..$^{19}$ The Convention for the Protection of Human Rights and Fundamental Freedoms of 1950 contains no information about the right to a constant place of residence in a given country and offers no guarantees against the possibility of expulsion from that country. Article 4 of the Protocol No. 4 to the Convention for the Protection of Human Rights and Fundamental Freedoms of 1950, however, forbids mass expulsion of foreigners: 'Collective expulsion of aliens is prohibited'. Even the wording is identical with the one featuring in the Charter. ${ }^{20}$ Thus, according to paragraph 3 of Article 52 of the Charter, the prohibition of collective expulsions - stipulated in Article 19 of the Charter - shall apply in the same manner and under the same conditions as the identical prohibition stipulated in Article 4 of Protocol No 4 to the Convention for the Protection of Human Rights and Fundamental Freedoms of 1950. ${ }^{21}$

Furthermore, Article 19 of the Charter forbids the expulsion or extradition of any person to a State "where there is a serious risk that he or she would be subjected to the death penalty, torture, or other inhumane or degrading treatment or punishment'. These provisions of paragraph 2 of the said article can be logically derived from the stipulations of articles 2 and 4 of the Charter, and represent a recognition of the case practice of the European Court of Human Rights in

18 Цапенко И.П. Как противостоять нелегальной миграции // Вопросы экономики. - 2001. - №9. - С. $147-148$.

19 Charter of Fundamental Rights of the European Union. (2000/C 364/01) [http://www.europarl. europa.eu/ charter/pdf/text_en.pdf], accessed on the $27^{\text {th }}$ of December 2015.

20 Ильин Ю. Д. Лекции по истории и праву Европейского Союза. - М.: Спарк, 2002.

21 European Convention on Human Rights. [http://www.echr.coe.int/Documents/Convention ENG. pdf], accessed on the $27^{\text {th }}$ of December 2015. 
interpretation of Article 4 of Protocol No 4 to the Convention for the Protection of Human Rights and Fundamental Freedoms of 1950.

Pleas submitted by immigrants challenging the resolution of a Member State to expel or deport them are considered by the European Court on Human Rights. These pleas usually invoke possible violations of Article 3 of the Convention for the Protection of Human Rights and Fundamental Freedoms of 1950, referring to the prohibition of torture and inhumane treatment. Nevertheless, the Commission envisaged measures applicable to cases where there are reasons to believe that the person will be treated as it is forbidden by Article 3 of the Convention for the Protection of Human Rights and Fundamental Freedoms of 1950. Furthermore, it is the Commission's competence and right to estimate the risks, which will be incurred by various individuals after expulsion or deportation. (However, Article 16 of the Basic Law of Germany, Article 13 of the Constitution of Spain, Article 19 of the Constitution of Romania, and Article 47 of the Constitution of Slovenia provide protection against expulsion and extradition.)

In 2005-2006, the EU countries founded the Frontex agency. 30 million euros were allocated for this project. The purpose of this agency is to reduce the inflow of economic migrants to EU territory. National governments are expected to deal with all legal issues concerning repatriation, while the Agency is responsible for organizing the departure of illegal immigrants. Besides allocating annual budgets to the Agency, the representatives of the European Commission are also active in terms of developing departure rules for persons who failed to obtain a new citizenship and of elaborating departure procedures which do not violate the civil rights of the respective persons. The frequency and the destinations of flights will depend on the needs of European Union countries. The EU has already concluded agreements on readmission of citizens with Albania, Hong Kong, Macau, and Sri Lanka. ${ }^{22}$

\section{Conclusion (Based on Extant Legislation)}

It is necessary to consider three sets of basic elements regarding the organization of immigration. These are explained in detail below.

1) Measures aiming to protect the interests of migrant workers:

- Simplification of departure conditions and of readmission to the countries of origin by means of amending national legislations. Dismantling, where this is the case, state monopoly in the field of labour export management; the creation of national-level private agencies by firms engaged in international employment mediation and/or admitting foreign organizations engaged in such activities to various countries could serve the same purpose.

22 Нелегальных иммигрантов будут вывозить из Европы на чартерных рейсах // [htpp://pda.lenta.ru/ world/2004/01/25charter/], accessed on the $1^{\text {st }}$ of October 2015. 
-Establishment of minimum requirements regarding the content of employment contracts (e.g., general terms, duration, salary, taxation, and insurance);

- Protection of rights enjoyed by migrant workers in their host countries (conclusion of multi- and bilateral intergovernmental agreements on relevant matters);

- Supporting the expeditious and productive adaptation of migrant workers to the new working conditions extant in the host countries and re-adaptation on return to their countries of origin. The comprehensive activities aimed at presenting and explaining working conditions and life abroad, the language teaching and vocational training programmes preceding the migrants' trips abroad solve the first problem. The second is solved by assistance in terms of welfare provision after return. ${ }^{23}$

2) Measures aiming to protect the state interests of labour donor countries:

- Licences issued by public administration authorities to companies organizing export of labour. The purpose is to restrict the right of mediating employment abroad only to organizations that have sufficient knowledge as well as experience in the field and are also capable of assuming pecuniary as well as legal responsibility for the results of this activity.

- Regulating (both the quantitative and qualitative) parameters of labour outflow. Such policies are required for protecting national labour markets from the 'flight' of professionals trained in rare specialties and for preventing various negative consequences of emigration on demographic processes in the respective country. This can be achieved by a wide range of measures, such as: restrictions on issuing international passports and express prohibition of departure or introduction of migratory quotas for certain categories of specialists. Economic methods may be applied, too; for example: differentiation - depending on the migrant workers' professions - of wages paid in foreign currency. A system of penalties may also be introduced, the most severe punitive measure being the confiscation of property for unauthorized departure from the country.

- Attraction of currency to the country. Foreign currency stems in this case, first of all, from the migrant workers themselves, who are bound to transfer a certain part of their earnings in foreign currency to their countries of origin or to make investments in their homelands.

3) Measures for the mutual protection of labour importing and exporting countries:

- Multi- and bilateral agreements on labour migration, which stipulate that migrant workers shall return to their home countries after the duration of their contracts has expired;

23 Тарлецкая Л. Международная миграция и социально-экономическое развитие // МЭиМО. - 1998. - №7. - C. 140 . 
- Carrying out joint, co-ordinated actions with the purpose of minimizing illegal migration. ${ }^{24}$ It should be noted that people will not leave their home countries if three main conditions are met: the respective country's economy develops dynamically; social living conditions gradually improve; a safe life combined with the observance of civil rights and political freedoms can be secured within the borders of their home countries. ${ }^{25}$

The inefficiency of certain instruments, similar to the ones listed above, is practically always explained by the fact that they influence only separate parameters, and not the entire complex of reasons for migratory mobility. Similarly, certain measures may also be ineffective if they are applied separately, in isolation from one another, or if they are not reinforced and enforced by political means and are not applied in concert with the latter when it is necessary.

Finally, the matters regarding the organization of immigration, as presented in this paper, raise an interesting question: will the modern Europe evolve to be a new civilization synthesising traditional values and representations of European peoples as well as the civilization values of immigrants (who come primarily from Muslim countries) or the united Europe will develop effective mechanisms of civilization absorption targeting the people who (will) arrive to its territory?

\section{References}

Charter of Fundamental Rights of the European Union. (2000/C 364/01) [http:// www.europarl. europa.eu/charter/pdf/text_en.pdf], accessed on the $25^{\text {th }}$ of December 2015.

Communication from the Commission to the Council and the European Parliament on a Common Policy on Illegal Immigration (COM /2001/ 0672 final). [http:// eur-lex.europa.eu/legal-content/EN/TXT/?uri=CELEX: 52001DC0672], accessed on the 25th of December 2015.

Convention Determining the State Responsible for Examining Applications for Asylum Lodged in One of the Member States of the European Communities - Dublin Convention. (97/C 254/01) [http://eur-lex.europa.eu/legal-content/ EN/ALL/?uri=CELEX\%3A41997A0819\% $2801 \% 29$ ], accessed on the $27^{\text {th }}$ of December 2015.

Council Directive 2005/85/EC of 1 December 2005 on Minimum Standards on Procedures in Member States for Granting and Withdrawing Refugee Status.

24 Пахомова Н. Регулируемая миграция как инструмент демографической политики. Диалог. UA, 25 ноября, 2005. [htpp://dialogs.org.ua/ru/material/full/2/4146], accessed on the $1^{\text {st }}$ of October 2015.

25 Цапенко И. П. От миграционного контроля к управлению миграционными процессами // МЭиМО. -2001. - №10. - С. 32 
[http://eur-lex.europa.eu/legal-content/GA/TXT/?uri=URISERV:133140], accessed on the $27^{\text {th }}$ of December 2015.

[Council of the European Union:] European Pact on Immigration and Asylum. [http://register.consilium.europa. eu/doc/srv?]=EN\&f=ST\%2013440\%20 $2008 \% 20 I N I T]$, accessed on the $25^{\text {th }}$ of December 2015.

Council Regulation (EC) No 539/2001 of 15 March 2001 Listing the Third Countries

Whose Nationals Must Be in Possession of Visas When Crossing the External Borders and Those Whose Nationals Are Exempt from That Requirement. [http:// eur-lex.europa.eu/legal-content/EN/ALL/?uri=CELEX\%3A32001R0539], accessed on the $25^{\text {th }}$ of December 2015.

Directive 2009/52/EC of the European Parliament and of the Council of 18 June 2009 Providing for Minimum Standards on Sanctions and Measures against Employers of Illegally Staying Third-Country Nationals. [http://eur-lex.europa. eu/legal-content/GA/TXT/?uri=celex: 32009L0052], accessed on the $25^{\text {th }}$ of December 2015.

[European Commission: Migration and Home Affairs.] External Borders Fund. [http://ec.europa.eu/dgs/home-affairs/financing/fundings/migration-asylumborders/external-borders-fund/index_en.htm], accessed on the $25^{\text {th }}$ of December 2015.

[European Commission: Migration and Home Affairs.] Return Fund. [http:// ec.europa.eu/ dgs/home-affairs/financing/fundings/migration-asylumborders/return-fund/index_en.htm], accessed on the $25^{\text {th }}$ of December 2015.

European Convention on Human Rights. [http://www.echr.coe.int/Documents/ Convention_ENG. pdf], accessed on the $25^{\text {th }}$ of December 2015.

Green Paper on a Community Return Policy on Illegal Residents. (COM/2002/175 final) [http://eur-lex.europa.eu/ legal-content/EN/ TXT/?uri=celex:52002DC0175], accessed on the $25^{\text {th }}$ of December 2015.

The Hague Programme. 10 Priorities for the Next Five Years. [http://eur-lex. europa.eu/legal-content/EN/TXT/?uri= uriserv:116002], accessed on the $25^{\text {th }}$ of December 2015.

Proposal for a Comprehensive Plan to Combat Illegal Immigration and Trafficking of Human Beings in the European Union. Official Journal, C 142, 14 June 2002. [http://eur-lex.europa.eu/legal-content/EN/TXT/?uri=URISERV: l33191b], accessed on the $25^{\text {th }}$ of December 2015.

Нелегальных иммигрантов будут вывозить из Европы на чартерных рейсах // [htpp:// pda.lenta.ru/world/2004/01/25charter/], accessed on the $1^{\text {st }}$ of October 2015.

Гудвин-Гилл Г.С. Статус беженца в международном праве. М., 1997.

Юдина Т.Н. О социологическом анализе миграционных процессов // Социологические исследования. - 2002. - №10. - С. 19-25.

Ильин Ю. Д. Лекции по истории и праву Европейского Союза. - М.: Спарк, 2002. 
Кудрина Л.В. Пространство свободы, безопасности и правопорядка. // Европейский Союз: факты и комментарии. - №48. // [http://www.edcaes.ru/site/ru/union/ archive/ vipusk_48.html], accessed on the $1^{\text {st }}$ of October 2015.

Потёмкина О. Иммиграционная политика ЕС: от Амстердама до Лиссабона // МЭ и MO. - 2010. - № 4. - C. 42-51.

Потёмкина О. Сотрудничества в сфере внутренних дел и правосудия // Европейский союз на пороге XXI века: выбор стратегии развития / Под ред. Борко Ю. А и Буториной О. В. - М.: Эдиториал УРСС, 2001. - С. 210.

Пахомова Н. Регулируемая миграция как инструмент демографической политики. Диалог. UA, 25 ноября, 2005. [htpp://dialogs.org.ua/ru/material/full/2/4146], accessed on the $1^{\text {st }}$ of October 2015.

Тарлецкая Л. Международная миграция и социально-экономическое развитие // МЭиМО. - 1998. - №7. - С. 140

Цапенко И. П. Как противостоять нелегальной миграции // Вопросы экономики. 2001. - №9. - С. 147-148.

Цапенко И. П. От миграционного контроля к управлению миграционными процессами // МЭиМО. - 2001. - №10. - С. 32. 